\title{
AFIRMAÇÃO ÉTNICA E EDUCAÇÃO ESCOLAR INDÍGENA DO POVO MUNDURUKU DE MARITUBA (BELTERRA-PARÁ)
}

Anselmo Alencar Colares

UFOPA

\section{RESUMO}

$\mathrm{O}$ artigo trata de educação escolar indígena na Aldeia de Marituba (Município de Belterra, Pará), constituída por cerca de trinta famílias que reivindicam a demarcação de suas terras, após terem sido praticamente expulsas de onde moravam durante a criação da Floresta Nacional do Tapajós. Considerando que a Constituição Federal, a LDB e vários outros dispositivos legais garantem a educação diferenciada para os indígenas, buscou-se entender a concretização deste direito para um grupo que precisou recriar sua identidade, após décadas de quase total integração com a cultura não indígena, num processo intencional de aculturação dos indígenas à vida regional. Na luta pela permanência em suas terras, os membros da comunidade tiveram outros aprendizados, entre os quais o de que poderiam ser reconhecidos como indígenas, tais como seus antepassados da etnia Munduruku. A pesquisa foi realizada a partir de visitas in loco, quando se realizaram rodas de conversa com membros da comunidade e, depois, aplicação de um instrumento de coleta de informações mais específicas para os alunos indígenas. Os resultados demonstram que a escola existente, apesar de considerada indígena pela Secretaria Municipal de Educação e pela Secretaria Estadual de Educação, de fato não atende aos requisitos essenciais que caracterizam esta modalidade de ensino.

Palavras-chave: Educação indígena; recriação de identidade; escola diferenciada.

\section{ETHNIC AFFIRMATION AND INDIGENOUS SCHOOL EDUCATION OF THE MUNDIKURU PEOPLE FROM MARITUBA (BELTERRA-PARÁ)}

\begin{abstract}
This article deals with indigenous school education in the village of Marituba (Municipality of Belterra, Pará), consisting of about thirty families who demand the demarcation of their land, after being nearly evicted from where they lived during the creation of the Tapajos National Forest. Considering that the Federal Constitution, the LDB and various other legal provisions guarantee differentiated education for indigenous peoples, we have tried to understand the realization of this right for a group that had to recreate their identity after decades of almost total integration with non-indigenous culture, as part of an intentional process of acculturation of the indigenous to regional life. In the struggle to stay on their land, members of the community have learned other things, among which is the fact that they could be recognized as indigenous, such as their Munduruku ancestors. The research was carried out in loco, through conversations with community members, and the use of an instrument to collect more specific information from indigenous students. The results indicate that the existing school, despite claims to the contrary by both the State and the Municipal Board of Education, in fact does not meet the essential requirements that characterize indigenous school education.

Keywords: Indigenous education; identity re-creation; differentiated school.
\end{abstract}




\section{Introdução}

A Constituição Federal de 1988 estabeleceu que os índios têm direito ao uso das línguas maternas e de seus processos próprios de aprendizagem, por meio de uma escola específica. Os anos 1990 caracterizaram-se, neste campo, pela implementação da educação bilíngüe e intercultural, elaboração de currículos específicos e diferenciados, e desenvolvimento de processos próprios de ensino e aprendizagem considerando a diversidade entre os povos indígenas.

Além da nossa Carta Magna e da legislação nacional infraconstitucional, há uma série de documentos internacionais dos quais o Brasil é signatário, e que tratam de direitos dos povos indígenas. Dentre eles as Convenções 107 e 169 da Organização Internacional do Trabalho (OIT) e a Declaração sobre os direitos dos povos indígenas da Organização dos Estados Americanos (OEA). Com relação a questão educacional, destacam-se: a) Publicação do Decreto $n^{\circ}$ 26/91, da Portaria Interministerial $n^{\circ}$ 559/91 e das Portarias MEC 60/92 e 490/93, assim como a sanção da Lei 9.394/96, a divulgação do Referencial Curricular Nacional para as Escolas Indígenas (RCNEI) e a aprovação das Diretrizes Curriculares Nacionais da Educação Escolar Indígena (Parecer $n^{\circ} 14 / 99$ e Resolução ${ }^{\circ}$ 3/99 do Conselho Nacional de Educação), além de itens constantes no Plano Nacional de Educação, e nas legislações estaduais e municipais.

No âmbito do Ministério da Educação, foi criada a Coordenação Geral de Educação Escolar Indígena (CGEEI) visando cumprir os princípios e os objetivos estabelecidos na legislação e pôr em prática uma política nacional de Educação Escolar Indígena. Tem atribuições de planejar, orientar, coordenar e acompanhar a formulação e a implementação de políticas educacionais voltadas para as comunidades indígenas, apoiar técnica e financeiramente a formação de professores indígenas e o desenvolvimento de materiais pedagógicos específicos para as escolas indígenas. A coordenação atua também apoiando e estimulando a produção e distribuição de material didático, de autoria indígena, em línguas indígenas, bilíngües e em português, para uso nas escolas indígenas. Outra função da CGEEI é a articulação entre as diferentes esferas de governo (municipal, estadual e federal) e até mesmo entre diferentes unidades da federação. Diversas ações já foram realizadas ou estão em curso, mas ainda se faz necessário ampliar e fortalecer o processo de conquistas dos povos indígenas, fruto das lutas e reivindicações oriundas das necessidades reais e que se apresentam de forma bastante heterogênea.

Um item importantíssimo na temática da educação escolar indígena é, sem dúvida, a formação dos professores. Sem que esta questão seja enfrentada, todas as outras iniciativas podem resultar em grandes fracassos. A formação inicial e continuada dos professores índios deve ocorrer em serviço e simultaneamente à sua própria escolarização. Isto exige a elaboração de programas diferenciados que atendam a estas especificidades.

Tal formação implica em capacitar para a elaboração de currículos e programas específicos para as escolas indígenas, para o ensino bilíngüe, no que se refere à metodologia de ensino e na condução de pesquisas de caráter antropológico, visando à sistematização e incorporação dos conhecimentos e saberes tradicionais das sociedades indígenas, assim como a elaboração de materiais didático-pedagógicos, bilíngües ou não, para uso nas escolas instaladas em suas comunidades.

A educação escolar indígena, intercultural e bilíngue, já se constitui diferenciada por princípio, em decorrência de sua localização e inserção social. Mas a diferenciação não se esgota nestes aspectos. A pluralidade de povos demanda respeito por muitas diferenças que nem sempre são contempladas. É o caso das escolas indígenas das localidades similares a que foi contemplada nesta pesquisa. 
Este artigo resulta de uma pesquisa que teve como locus de investigação a comunidade de Marituba, no interior da Amazônia (município de Belterra, Pará) onde residem indígenas da etnia Munduruku que lutam pelo reconhecimento de sua identidade étnica, bem como pela demarcação de suas terras, mesmo enfrentando diversos preconceitos pelo fato de que, como alegam os que discordam de suas reivindicações, já estarem completamente integrados à cultura não-indígena.

Foto 1: Aldeia Munduruku-Marituba, em Belterra-PA

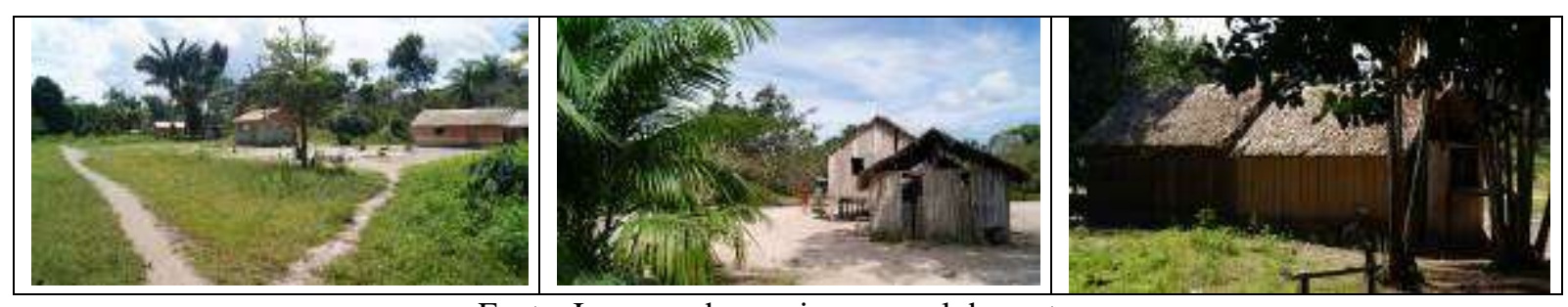

Fonte: Imagens do arquivo pessoal dos autores

A pesquisa foi realizada a partir de visitas in loco, rodas de conversa com membros da comunidade e aplicação de um instrumento de coleta de informações mais específicas para os alunos indígenas. Os tópicos a seguir expressam os aspectos mais relevantes que foram considerados para a compreensão do objeto estudado.

\section{A luta pela afirmação étnica do Povo Munduruku de Marituba}

Data do final da década de 1990 a eclosão do movimento de reelaboração da identidade indígena ${ }^{1}$ de parte das populações que se encontram na área de duas reservas de proteção ambiental: Floresta Nacional do Tapajós (Flona Tapajós), criada em 1974; e Reserva Extrativista Tapajós-Arapiuns (Resex Tapajós-Arapiuns), criada em 1998, ambas situadas em uma área que o IBGE denomina como microrregião do Médio Amazonas Paraense, também identificada como Baixo Amazonas ou Região do Baixo Rio Tapajós.

Imagem 1: Localização das Reservas Flona Tapajós e Resex Tapajós-Arapiuns

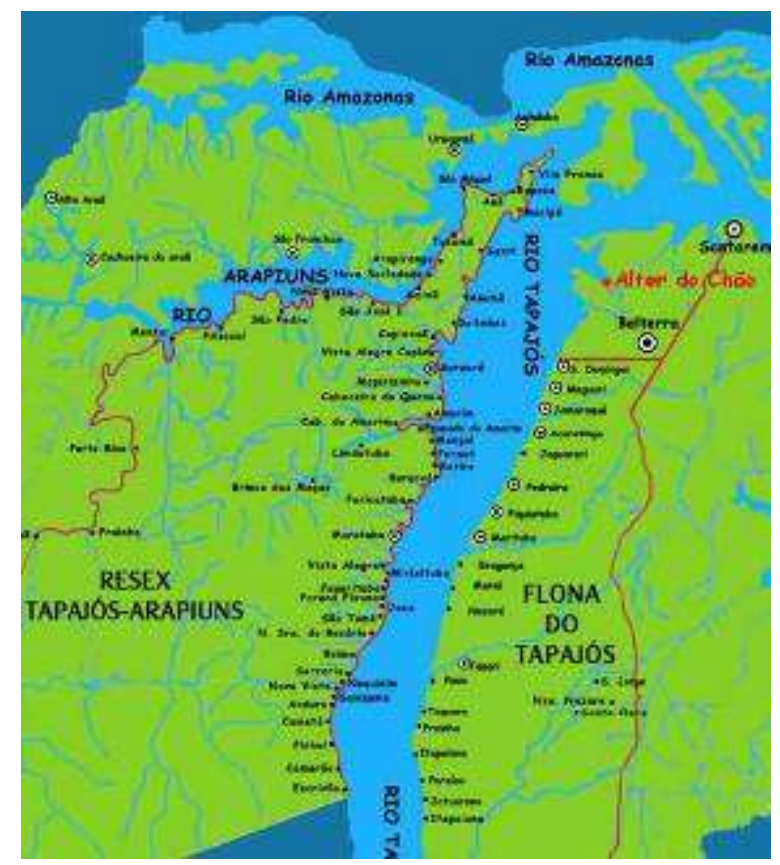

Fonte: http://maenaturezaecoturismo.files.wordpress.com/2010/01/mapa-flona-copy.jpg 
Desde finais do século XIX a região acima caracterizada era tida como desabitada, reconhecendo-se como extintos os grupos indígenas reconhecidos pelos colonizadores. Por conseguinte, o movimento de reafirmação enfrentou e ainda enfrenta muitas resistências e preconceitos, mas tem logrado êxito, especialmente o de incluir no debate acadêmico e político a situação destes povos, depois de um longo silêncio que lhes foi imposto. A criação das reservas ocorreu de forma abrupta e sem considerar a presença e a atividade das pessoas e foi o estopim para o movimento de reafirmação étnica.

A Flona do Tapajós foi criada tendo por objetivo a exploração sustentada de madeira, ocupando uma área de aproximadamente 600 mil hectares, limitando-se a oeste com o Rio Tapajós, ao leste com a rodovia Santarém-Cuiabá, e ao sul com o Rio Cupari. Foi a primeira reserva florestal efetivamente implementada na Amazônia, conduzida pelo extinto IBDF. Atualmente está sob a responsabilidade do Instituto Brasileiro do Meio Ambiente e dos Recursos Naturais Renováveis (IBAMA) e do Instituto Chico Mendes, órgãos do Ministério do Meio Ambiente (ICMBIO).

Imagem 2: Floresta Nacional do Tapajó

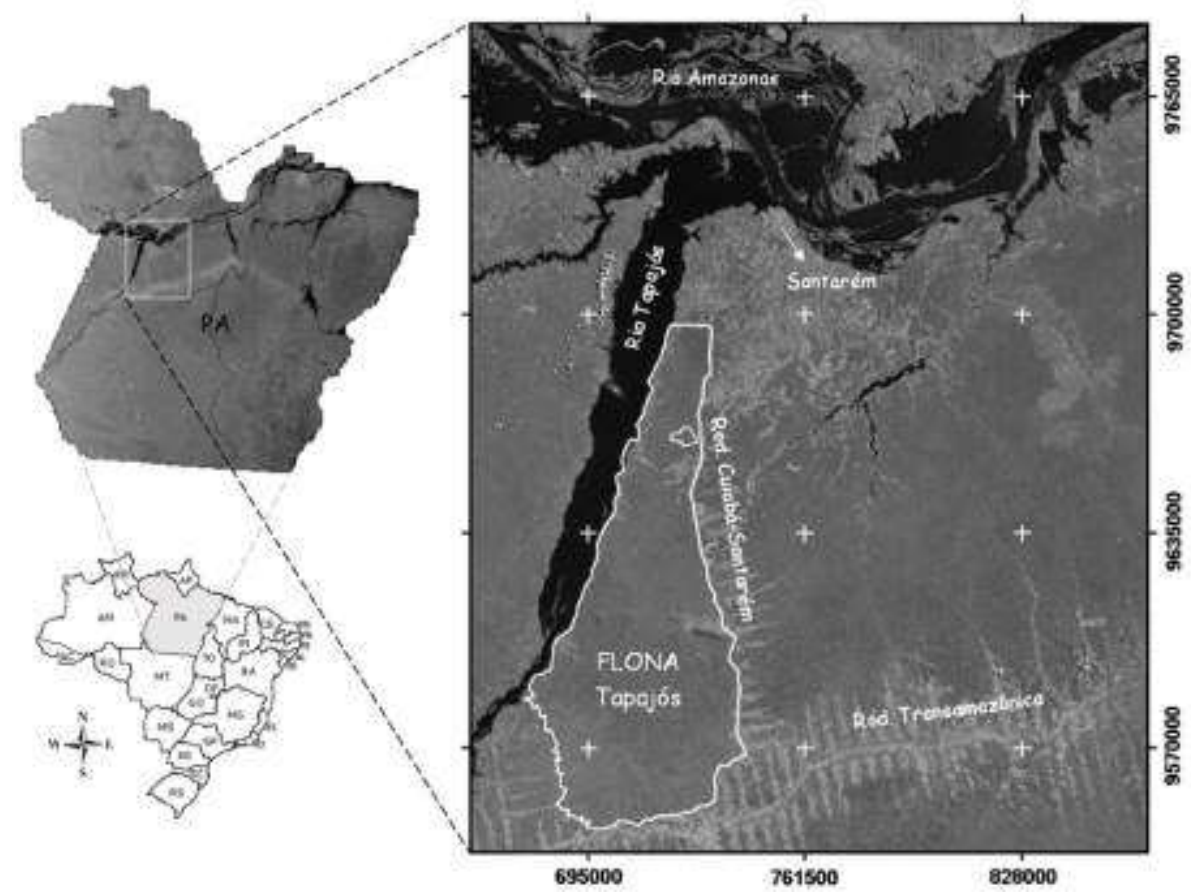

Fonte: http://acta.inpa.gov.br/fasciculos/38-2/BODY/v38n2a06.html\#figura1

A Flona Tapajós teve seus limites sobrepostos aos territórios das diversas comunidades, mas a legislação então em vigor não permitia a permanência de nenhum residente no interior das reservas. Desta forma, teve inicio um processo de desapropriação das terras das populações que lá se encontravam, o que acabou gerando intensos conflitos.

As comunidades da margem direita do Tapajós, organizaram-se e iniciaram um movimento de forte resistência para permanecer em suas terras e assegurar o acesso aos recursos florestais, travando diversos embates com o órgão ambientalista governamental. $\mathrm{O}$ Sindicato dos Trabalhadores Rurais de Santarém foi o principal instrumento de articulação política das comunidades, auxiliando-as na luta em prol da autodemarcação de uma área para que fosse excluída dos limites da Flona Tapajós. 
Inicialmente esta foi a principal motivação para que os habitantes da comunidade se organizassem em torno de uma causa comum. Como resultado concreto do movimento, o IBDF admitiu excluir uma área de 27.600 da Flona Tapajós para as comunidades, todavia, esse tamanho era inviável para que as populações garantissem sua sobrevivência, tendo em vista que praticavam uma agricultura incipiente e dependiam fortemente do extrativismo. Foram contratados os serviços topográficos do $8^{\circ}$ Batalhão de Engenharia e Construção ( $8^{\circ}$ BEC) para fazer a demarcação, cujo início ocorreu em setembro de 1983, mas os comunitários impediram que o trabalho fosse executado, partindo eles próprios para fazer a demarcação que desejavam, em maio de 1984. A nova linha demarcatória, distante aproximadamente dez quilômetros da margem do rio até o centro de floresta foi denominada "Pico das Comunidades", em oposição ao "Pico do IBDF". A administração da Flona Tapajós não reconheceu tais limites, o que levou a continuidade dos embates até finais da década de 1990, quando houve mudança na legislação das Florestas Nacionais, permitindo a partir de então a permanência das populações na área daquela reserva.

Foi neste processo de luta que eclodiu o movimento de reafirmação étnica do povo Munduruku que vivia na Flona do Tapajós inicialmente desencadeada na localidade Taquara, seguido por Marituba e Bragança. Até então, a maioria das pessoas não participava de qualquer forma de organização política que representasse seus interesses. Da luta pela permanência passaram a exigir o reconhecimento indígena e a demarcação de suas terras.

A Fundação Nacional do Índio (FUNAI) viabilizou a realização de estudos, sendo que as populações das três localidades já foram reconhecidas como integrantes da etnia Munduruku, mas ainda não foi concluído o trabalho visando a demarcação de suas terras e a consequente legalização da área indígena e de suas respectivas aldeias. Ressalte-se que as escolas existentes nas localidades já são reconhecidas como indígenas (sobre esta questão se discorrerá em maiores detalhes no tópico dedicado a educação escolar indígena).

Um aspecto relevante a ser considerado na análise histórica destas duas décadas de lutas e de afirmação da identidade indígena destes povos foi a sucessiva mudança na denominação do coletivo. Sob os efeitos do projeto geopolítico de expansão das fronteiras econômicas da Amazônia, desenvolvido pelos governos militares a partir de meados da década de 1960, as populações foram comumente identificadas como 'caboclas' (BECKER, 1992) ${ }^{2}$. Trata-se de um termo carregado de conotações pejorativas e nem sempre bem aceito por quem assim é chamado, embora seja de amplo uso na Amazônia, como se fosse uma maneira "carinhosa" de tratamento. Todavia, vários autores explicam que o termo caboclo não se refere a autoidentificação, mas a uma forma de caracterizar o outro como inferior (LINS e SILVA, 1980).

Posteriormente, no contexto das disputas sobre a posse e controle de suas terras, desencadeadas a partir da década de 1970, quando interesses econômicos ligados à indústria madeireira se instalaram na região e avançaram sobre seus territórios, ganhou expressividade a denominação "população tradicional”.

Quando a Flona Tapajós foi criada, e sua administração empreendia esforços para desapropriar as terras, as populações eram descritas como 'caboclas', 'ocupantes ocasionais' 'posseiras', e até como 'invasoras'. Na medida em que se organizaram e resistiram a demarcação oficial passaram a ser identificadas como "comunidades tradicionais' ou 'comunidades ribeirinhas'. Em finais da década de 1990, novamente ocorreram mudanças nas formas de identificação dessas populações, com a caracterização específica dos povos que assumiram a condição indígena.

Frente a todas as formas pejorativas de identificação, os grupos populacionais se contrapuseram sistematicamente, configurando um campo de disputas identitárias 
(BOURDIEU, 2003). O "caboclo", cultural e territorialmente destituído, ao se organizar coletivamente foi sendo reconhecido e se auto reconhecendo em sua identidade étnica. Desse modo, as alterações nas formas de tratamento da identificação do coletivo, estão diretamente relacionadas às disputas sobre o acesso e o controle dos territórios. Assim, o movimento foi se constituindo, e o "caboclo" que foi cultural e territorialmente destituído e quase expulso das terras que ocupava, passou a se constituir em uma comunidade tradicional concebida junto às reservas ambientais, até a luta pelo reconhecimento de sua identidade indígena e de seus territórios como 'terra indígena'.

Estes povos indígenas que hoje lutam para terem suas terras demarcadas e serem reconhecidos em suas etnias de origem, carregam uma história marcada por sucessivas investidas desagregadoras de suas formas originais de existência, até que passassem a ter praticamente o mesmo padrão de organização sociocultural e de ocupação da terra. Os diferentes grupos indígenas situados nas áreas das duas reservas florestais são vítimas de um longo e perverso processo de contato, iniciado no século XVII quando os colonizadores adentraram o Rio Tapajós, causando profundas transformações nas suas instituições e modos de vida. O primeiro movimento desarticulador foi promovido pelas Missões Jesuíticas, estabelecidas em cinco localidades da região do baixo Tapajós ${ }^{3}$, nas quais etnias diversas foram reunidas sob uma mesma base linguística, de culto religioso (ai compreendida a concepção religiosa) e de organização e finalidade do trabalho. Desta forma, estabeleceu-se uma suposta unidade, mesclando as diferenças culturais e afirmando a unidade linguística assentada na Língua Geral, conhecida como Nheengatu (BESSA FREIRE, 2003).

As missões cumpriram um duplo papel: assegurar o alargamento das fronteiras coloniais lusitanas e promover a homogeneização cultural e linguística. Posteriormente a investida com vistas a negar as identidades indígenas se deu por meio do Diretório dos Índios, política pombalina que forçando novas formas de organização sociocultural atendia aos interesses da exploração agrícola que se intentava para a Amazônia, pela disponibilização de mão de obra em maior quantidade (MOREIRA NETO, 1971).

Outro acontecimento de grande impacto na desestruturação do modo de vida dos povos da Amazônia foi a Cabanagem (ocorrida nas décadas de 1830-40), e que foi o mais popular entre os movimentos de rebelião contra as forças imperiais. A denominação foi dada por ter sido conduzido, em sua grande expressão, pelas populações indígena, negra e mestiça (DI PAOLO, 1990). Teve ainda como singularidade a efetiva tomada de poder político pelas forças rebeldes, o que gerou fortes implicações para os grupos nativos do baixo Tapajós, onde se conformou um dos principais focos de resistência (DI PAOLO, 1990; REIS, 1979; SANTOS, 1999). Mais de 30 mil pessoas, um quinto da população da região amazônica da época morreu nos confrontos com as forças bélicas do Império brasileiro.

A Cabanagem, em sua última fase, transbordou como uma grande enchente das margens conhecidas da luta política e fez renascer o orgulho de uma Amazônia indígena, que saiu de sua letargia para dar o troco de dois séculos e meio de atrocidades. Foi o último suspiro, o derradeiro extertor de um tempo sem possibilidade de volta. Ao retomar pela negatividade à identidade perdida pelo assalto colonial, as massas cabanas indicaram definitivamente não existir integração possível entre as sociedades tribais e as sociedades nacionais que nasceram da colonização europeia. (SOUZA, 2009, p. 212). 
A intensa e violenta repressão resultou grandes movimentos de fuga, provocando uma 'reinteriorização' das populações indígenas, depois de dois séculos em que grande parte havia sido 'descida' para residir nas Missões dos Jesuítas. As margens do rio Tapajós ficaram praticamente esvaziadas. O naturalista inglês H. Bates (1979) circulando pela região na década de 1850 , registrou que a Cabanagem teria causado uma diminuição de $30 \%$ da população. Outros naturalistas apontam a ausência de grupos indígenas, restando apenas vestígios de suas aldeias (COUDREAU, 1977, p. 17). Na verdade, houve um retorno dos indígenas para o interior das matas, situação que só se alterou em fins do Século XIX com o desenvolvimento da economia da borracha.

Os grupos nativos remanescentes mantinham poucos e diferenciados vínculos entre si, os quais resultavam basicamente dos laços de parentesco, ou quando da realização das festividades, notadamente religiosas. As ameaças aos seus territórios e o movimento de resistência impetrado quando da criação da Flona do Tapajós, estreitaram as relações entre eles, gerando uma nova unidade sociopolítica. É neste contexto que se situa o nascimento da organização dos povos do Tapajós em busca de serem reconhecidos como indígenas.

\section{Conquistas gradativas, mas permanentes}

As populações residentes na área de reserva de proteção ambiental Flona do Tapajós estão obtendo alguns frutos da luta que passaram a empreender em defesa de seus interesses. A nova versão do Sistema Nacional de Unidades de Conservação (SNUC), aprovada e sancionada em 2000 (Lei Federal no 9.985, de 18 de julho de 2000). No artigo 17, amplia o conceito da categoria de reserva Floresta Nacional, designando-a para o "uso múltiplo sustentável dos recursos naturais" e não apenas para a exploração madeireira, como era anteriormente. Também estabelece que nela "é admitida a permanência de populações tradicionais". O SNUC também contempla 'populações tradicionais' em outras duas categorias: nas Reservas de Desenvolvimento Sustentável (RDS) e nas Reservas Extrativistas (RESEX). Identificadas como 'populações tradicionais' as comunidades da região tiveram assegurado o direito de permanecer em suas terras. Essa mudança na legislação afastou as ameaças de desapropriação.

Essa nova conformação reflete o processo de redefinição e reclassificação dos diversos segmentos sociais, agora determinado por critérios ecológicos. (ESTERCI, 2002). A incorporação da dimensão ambiental às identidades sociais conferiu maior legitimidade às reivindicações por direitos territoriais. Mas também realimentou a luta em prol do reconhecimento da identidade indígena e da demarcação das terras. Isto porque os modos de uso da terra e de exploração dos recursos estariam, a partir de então, condicionados às regulamentações das reservas.

O movimento de reafirmação das identidades indígenas nesta porção da Amazônia se estende além do rio Tapajós, com a participação de várias comunidades na área da Resex Tapajós-Arapiuns, e de grupos situados na margem esquerda do Rio Arapiuns e seus afluentes, mobilizando uma população estimada em 2,5 mil pessoas. Fruto da organização e da articulação com o movimento indígena nacional, no final do ano de 1999, aconteceu o "Primeiro Encontro Indígena", na localidade de Taquara, com a participação de representantes de várias comunidades do Tapajós e Arapiuns, e o apoio de órgãos governamentais e de movimentos populares. O encontro se repetiu nos meses seguintes em Marituba e Bragança, e igualmente seus moradores passaram a se reconhecer como pertencentes à etnia Munduruku. No ano 2000, houve a criação do Conselho Indígena dos Rios Tapajós e Arapiuns (CITA), mobilizando todos os indígenas do baixo Tapajós e hoje constituindo sua principal representação política. 
Dentre as dezoito comunidades que integravam a área territorial da Flona do Tapajós, apenas três - Taquara, Marituba e Bragança - se assumiram como indígenas. Afirmando sua identidade étnica, renegaram a denominação de caboclos, ou de 'população tradicional', assim como o modelo de ocupação de terra previsto na legislação da Floresta Nacional. Desta forma, se distanciaram dos demais grupos com os quais haviam compartilhado um histórico de lutas em defesa de suas terras, gerando algumas tensões, especialmente com aqueles que temem a perda de oportunidades vinculadas à exploração da madeira e de outros produtos extrativos.

Considerando que as aldeias mencionadas estão sob a jurisdição do município de Belterra, é importante registrar que tem havido um relacionamento produtivo com a esfera de governo municipal. Exemplo disso foi quando da elaboração do Plano Diretor Participativo, elaborado durante o ano de 2006 e sancionado em fevereiro de 2007 (Lei n ${ }^{\circ}$ 131), quando houve a participação de representantes indígenas nos trabalhos, sendo garantido no artigo 37, que as terras dos índios Mundurucu de Bragança, Marituba e Taquara configuram "Zonas Especiais de Interesse Cultural”.

A Prefeitura Municipal criou uma Coordenação Indígena, na Secretaria de Planejamento e Gestão, para tratar exclusivamente dos interesses dos indígenas do município. Em dezembro de 2007 foi efetivado o Conselho Indígena Munduruku de Belterra (CIMB). Além disso, as escolas de ensino fundamental em Bragança, Marituba e Taquara passaram a ser reconhecidas como 'escolas indígenas'.

\section{Educação Indígena e Educação Escolar Indígena}

Por educação indígena entende-se os processos próprios de produção e transmissão dos conhecimentos dos povos nativos4 do território brasileiro. Apesar das transformações pelas quais passam as culturas indígenas, algumas inclusive em ritmo acelerado, podemos dizer que os saberes ancestrais continuam sendo transmitidos oralmente de geração em geração, permitindo os aprendizados do cultivar a terra, caçar, pescar e encontrar na natureza as substâncias para a cura das enfermidades. A educação indígena desenvolve-se em momentos críticos durante o ciclo de vida, os quais, geralmente contam com cerimônias celebrativas e a participação de todo o grupo social. A educação indígena, portanto, compreende os processos pelos quais esses povos asseguram seus projetos de futuro, reproduzindo e reconstruindo a identidade, a tradição, os saberes, os valores, os padrões de comportamento e de relacionamento, na dinâmica própria de suas culturas. Os povos indígenas possuem espaços e tempos educativos dos quais participam a pessoa, a família, a comunidade e todo o povo. Deste modo, a educação é assumida como responsabilidade coletiva.

A educação escolar é apenas uma das formas encontradas pela civilização ocidental para sistematizar o processo de socialização de seus membros. Depreende-se, dessa maneira, que a educação escolar indígena, diz respeito aos processos de produção e transmissão dos conhecimentos não-indígenas e indígenas por meio da escola.

É extremamente importante reconhecer que os povos indígenas mantêm vivas as suas formas próprias de educação, e que estas podem contribuir na formulação de uma política de educação escolar capaz de atender aos anseios, interesses e necessidades da realidade hoje, diante das lutas pelo respeito e valorização da pluralidade e da autonomia dos povos na condução de seus destinos. Todavia, muitas vezes as propostas indígenas de escola provocam estranhamento e muita resistência, no que pese apontarem novas possibilidades educacionais. 
Foi necessária uma longa trajetória até que as próprias sociedades indígenas constatassem que a educação escolar, de "instrumento de opressão e integração forçosa", poderia tornar-se uma aliada, ferramenta de luta a favor de seus interesses, na dinâmica história de contato de cada um destes povos com a chamada "sociedade nacional".

A Resolução ${ }^{\circ}$ 03, de 10 de Novembro de 1999/CNE, sintetiza a conquista legal na elaboração do conceito de educação escolar indígena no Brasil. Ela fixa Diretrizes para o funcionamento das escolas indígenas e dá outras providências destacando os princípios e pressupostos que norteiam o novo ideário político-pedagógico desta escola.

A Resolução estabelece, entre outras diferenças, as "diretrizes curriculares do ensino intercultural e bilíngüe, visando à valorização plena das culturas dos povos indígenas e a afirmação e manutenção de sua diversidade étnica". Na prática, isto significa abrir espaço para a retomada da cultura, dos processos educacionais, de um tempo de relações vinculadas às experiências do cotidiano, à vivência dos alunos. Uma vivência mediada pela oralidade, pelos mitos, pela imitação. Significa abrir espaços para uma releitura da história, não mais contada só pelos livros. Significa, ainda, produzir novos textos, novos conteúdos. Nessa produção todos entram como autores, pesquisadores, mediadores do diálogo intercultural, recriando a escola. Apesar disso, como os professores procedem de diversos contextos sócio-políticos, a escola indígena acaba sendo tão singular quanto as próprias comunidades. Contudo isto não inviabiliza a educação escolar indígena, ao contrário, a alimenta. No caso estudado, a educação escolar está em sintonia com o que estabelece a legislação nacional. A Constituição de 1988 inaugurou no Brasil a possibilidade de novas relações entre o Estado, a sociedade civil e os povos indígenas, ao superar, no texto da lei, a perspectiva integracionista, e reconhecer a pluralidade cultural. Em outros termos, o direito à diferença fica assegurado e garantido, e as especificidades étnico-culturais valorizadas, cabendo à União protegê-las. Desde então, inúmeras normas legais (Decretos, Portarias, Diretrizes, Resoluções...) vêm sendo feitas, com destaque à problemática da escolarização indígena, no sentido de buscar a coerência com o texto constitucional. Pela primeira vez na história da legislação educacional brasileira, esse tema figurou na Lei de Diretrizes e Bases da Educação Nacional (LDB), com dois artigos específicos (78 e 79). A própria Constituição, em seu artigo 210, parágrafo $2^{\circ}$, já assegurava, além do uso das línguas indígenas, o direito aos processos próprios de ensinoaprendizagem.

Desde o início das discussões sobre a melhor escola para os índios, os especialistas têm lembrado que se deve diferenciar uma "educação indígena" de uma "educação escolar indígena". Ou seja, a educação indígena não se encerra nem jamais se encerrará na escola. Esta instituição foi forjada para transmitir alguns conhecimentos, e o faz a partir de preceitos e condições que estão longe de ser universais.

Cohn (2005) analisa um artigo em que o autor percorre diversas cosmologias indígenas, sugere que os índios pensam a distinção e a relação homem animal de modo inverso do nosso. Se nós tomamos o orgânico como denominador comum entre homens e animais, e se nesse modo de distinguir humanos de animais a diferença não está no corpo, mas, digamos, na alma, ou no fato do homem ser "o único animal racional" e a deter cultura, os índios pensam o oposto, ou seja, que homens e animais compartilham almas ou princípios vitais, sendo sujeitos de um mesmo tipo, diferentes apenas pelo estatuto ou forma de estar no mundo e em seus corpos. Para uns, a natureza é comum a homens e animais e a cultura exclusiva dos primeiros; para outros, a natureza é que difere, a cultura é que é comum. Por isso a ênfase indígena na metamorfose, como, por exemplo, a capacidade de xamãs de tomar formas corporais de animais e se comunicar com eles: porque os animais também são sujeitos no mundo e dotados, a seu modo, de cultura, estar 
em um novo corpo é adquirir uma nova perspectiva sobre o mundo, é ver o mundo como outro sujeito, os homens tornando-se objetos dessa perspectiva; é, no limite, abraçar outra cultura. Resumido assim, o argumento pode parecer banal ou fazer crer que, de fato, os índios têm uma visão errônea sobre o mundo. Mas ele vai exatamente no sentido oposto: o de que essas filosofias ou ciências indígenas devem ser tomadas a sério, pois revelam um preceito de entendimento do mundo, das relações entre homens e animais e sobre a atuação no mundo.5

Como, então, tratar de temas da biologia, da ecologia ou da geografia na escola indígena? Ou como tratar textos que remetem à mitologia, ela toda embasada nesses preceitos? Afinal, mais do que conteúdos diferentes, o que esse exemplo revela é que se trata de uma biologia, ou uma ecologia, diferente - no limite, de mundos sociais diferentes. Não basta ensinar taxonomia animal e dizer que nós e eles classificamos os animais de outro modo. Não há como fazer dialogar conteúdos e taxonomias: há de se fazer dialogar modos de ver e entender o mundo.

Outros exemplos podem ser vistos nos dilemas referentes ao ensino da história. Afinal, a temporalidade linear, a narrativa seriada e a cronologia são culturalmente definidos e ligam-se a uma variante cultural de se pensar o tempo, a passagem do tempo e sua causalidade. Não se trata de negar a historicidade, ou um sentido de história, mas reconhecer que ela se funda em preceitos radicalmente diversos dos que conhecemos. Assim, como contar nossa história sem negar-lhes a deles? Não contando versões da mesma história, mas explicitando, para começar, os preceitos historiográficos e temporais que dão forma a essas histórias. Fazendo-o, corremos menos riscos de subverter sua história, ou de dar a entender que são versões desviantes de uma história comum ou, ainda, erro bastante recorrente, reduzir relatos a mitos, como se esses fossem menos verdadeiros que a história.

Como essas questões têm sido resolvidas? Pela formação de professores capazes de construir currículos e gerir suas escolas e sua formação como "pesquisadores", ou seja, capacitados para construir conhecimentos a serem transmitidos na escola.

Apesar dos inegáveis avanços, resultante de reivindicações, lutas e mobilizações de movimentos dos próprios povos indígenas, com apoio de seus aliados, a difícil e complexa realidade das escolas indígenas aponta para o fato de que, na prática do estabelecimento de novas relações entre o Estado e os povos indígenas, ainda há muito a ser feito para que se concretize a escola indígena almejada pelos próprios povos indígenas. Até porque a escola indígena desejada não se limita a uma forma determinada de ensino e de aprendizagem, mas se articula com as demais formas concretas que correspondem a própria história dos povos indígenas.

\section{Educação escolar indígena (diferenciada, porém com qualidade)}

O livro "Educação e Sociedades Tribais", de Silvio Coelho dos Santos, publicado em 1975, é pioneiro na temática da educação escolar indígena no Brasil. O trabalho é baseado numa pesquisa realizada junto a postos indígenas da região sul no início da década de 1970. Três anos depois, Bartolomé Meliá, baseado num seminário do Conselho Indigenista Missionário - CIMI, realizado em 1978, publicou "Educação Indígena e Alfabetização", onde aprofundou a discussão da questão sobre a língua em que a alfabetização deveria se dar, e firmou o termo "educação para o indígena", ressaltando que as sociedades indígenas já possuem seu próprio sistema educacional e que a educação escolar deveria a ele se justapor e não a substituir. A década de oitenta assistiu ao 
crescimento do chamado movimento indígena, fruto do surgimento e consolidação de diversas organizações de educadores indígenas.

Fruto dos avanços na organização dos indígenas com vistas a elaboração e efetivação de propostas educacionais, desde 2001 foi instalada no MEC a Comissão Nacional de Educação Escolar Indígena, composta por professores e outros representantes indígenas titulares e suplentes, de diferentes regiões do Brasil. Sua função é de prestar assessoria e também propor políticas para esta modalidade de educação, sendo a única instância totalmente indígena a executar o controle social de uma política implementada pelo Estado Brasileiro." (GRUPIONI, 2003, p.151).

Em termos de Amazônia, Heck, Loebens \& Carvalho (2005) apontam a COIAB Coordenação das Organizações Indígenas da Amazônia Brasileira, como um dos mais importantes espaços de aglutinação e articulação. Hoje a COIAB congrega mais de cem organizações indígenas, de 165 povos.

No final da década de 1980, surgem as primeiras organizações de professores indígenas em diversas regiões do Brasil, com a intenção de discutir a implantação de uma política nacional específica para a Educação Escolar Indígena na perspectiva da melhoria da qualidade da educação diferenciada para os povos indígenas. Em busca de alternativas viáveis que solucionassem os problemas, foram organizados os primeiros encontros regionais de professores com um caráter de intercâmbio cultural, troca de experiências para sistematização dos primeiros documentos que permitiram refletir sobre o assunto. Assim, deu-se início ao processo de discussão sobre a educação escolar diferenciada por meio dos Encontros de Professores Indígenas ou Encontros de Educação Escolar Indígena.

De 13 a 18 de maio de 1988 foi realizado o I Encontro dos Professores Indígenas do Amazonas e Roraima, em Manaus, contando com a participação de 41 professores, representantes de doze povos dos dois Estados. A partir daí, nos anos posteriores foram realizados vários encontros, organizados pela Comissão dos Professores Indígenas do Amazonas e Roraima, que em 1989 transformou-se na Comissão dos Professores Indígenas do Amazonas e Roraima - COPIAR.

Os encontros propiciaram a produção de documentos decisivos para traçar o perfil da escola indígena, consoante com as reivindicações e os princípios de uma educação escolar indígena diferenciada por região e por etnia, como se pode conferir no caderno "Com As Próprias Mãos", organizado pelo Conselho Indigenista Missionário (1989). Naquele documento apareceram como prioridades as seguintes recomendações:

1. Definição dos currículos e regimentos específicos para as escolas indígenas elaborados pelos professores, juntamente com a comunidade, lideranças, organizações e assessorias; que fosse contemplada no currículo escolar a valorização das culturas, línguas e tradições dos povos indígenas;

2. Participação paritária de todos os segmentos da comunidade em todas as instâncias - consultivas e deliberativas de órgãos públicos responsáveis pela educação escolar indígena;

3. Formação específica e capacitação periódica para aprimoramento profissional;

4. Participação da comunidade indígena na defesa, conservação, preservação e proteção de seus territórios;

5. Garantia de assessorias especializadas para a realização de capacitação dos professores;

6. Substituição do termo monitor para professor, e que a escolha desses fosse feita pela comunidade, evitando os mesmos critérios utilizados para escolha do professor não indígena; 
7. Reconhecimento das escolas indígenas pelo Estado, por parte do Conselho Estadual de Educação;

8. Viabilizar o intercâmbio entre os professores para troca de experiências através da realização de eventos (cursos, encontros, seminários, congressos, conferências, etc.);

9. Destinar recursos para efetivação da formação específica e integral dos professores indígenas através do Governo Federal e Estadual;

10. Construir as escolas conforme arquitetura tradicional de cada grupo;

11. Priorizar o ensino da língua materna nas escolas e do português como uma $2^{\mathrm{a}}$ língua a ser ensinada;

13. Que os municípios, estados e União respeitassem e efetivassem as propostas apresentadas pelos professores dando os devidos encaminhamentos.

A mobilização e a participação do movimento indígena a partir dos anos 1970 asseguraram através da Constituição Federal de 1988 a normatização dos direitos dos índios, entre outros uma educação específica, bilíngue, multicultural, diferenciada e processos próprios de aprendizagem. O Referencial Curricular Nacional para a Educação Indígena (1998, p.25) ressalta que a escola indígena deve ser específica e diferenciada "concebida e planejada como reflexo das aspirações particulares de cada povo indígena e com autonomia em relação a determinados aspectos que regem o funcionamento $\mathrm{e}$ orientação da escola não-indígena".

Na década de 1980, o Acre saiu na frente, com cursos de formação específica para professores indígenas pela Comissão Pro-Índio - CPI/AC; o Amapá iniciou a formação no final da mesma década e, em Rondônia, aconteceu o primeiro curso de capacitação no início dos anos 1990.

A educação indígena diferenciada e de qualidade, é garantida ainda pela Convenção 169 da Organização Internacional do Trabalho - OIT (aprovada no Brasil pelo Decreto Legislativo $\mathrm{n}^{\circ} 143$ de 20 de junho de 2002) que conclama os governos membros a reconhecer o direito desses povos de criarem suas próprias instituições e meios de educação, possibilitando o ensino ministrado também na língua indígena, a formação de membros desses povos e a participação na formulação e execução de programas de educação de modo a atender as suas necessidades particulares, abrangendo sua história, seus conhecimentos e técnicas, seus sistemas de valores e todas as suas demais aspirações sociais, econômicas e culturais. Trata-se de uma proposta que visa romper com a concepção de educação massificadora em defesa de uma educação que respeite a diversidade cultural.

Com relação à formação de professores indígenas, esta não tem um modelo onde pautar-se, mas cabe aos próprios educadores a responsabilidade de uma construção coletiva dessa formação. Ao conquistarem o direito a uma escola específica e diferenciada, multicultural e comunitária os povos indígenas, abre-se um campo de estudos no qual, movimentam-se como protagonistas, no sentido de pensar o currículo a partir de outra lógica: a lógica do diálogo entre os seus saberes e os saberes legitimados historicamente pela cultura escolar.

\section{A escola indígena de Marituba}

A pesquisa que deu origem a este artigo foi intitulada "Retratos da educação escolar indígena no interior da Amazônia: estudo de caso na localidade Marituba-Pa (Aldeia Munduruku)", e desenvolveu-se a partir de visitas in loco, nas quais houve conversas com diversos membros da comunidade, a partir de agora identificada por Aldeia. A fotografia foi utilizada como recurso metodológico, assim como a escrita de pequenos textos pelos 
estudantes indígenas, instigados a realizar um contraponto entre a escola que frequentam e a escola de seus sonhos. Os sujeitos da pesquisa não falam mais a língua de seus antepassados - o Munduruku -, entretanto estão buscando recuperá-la, assim como outros hábitos e costumes. Nesse aspecto, a escola tem tido um papel relevante. Isto porque a instituição escola, embora carregue uma história homogeneizadora e etnocentrista (Missões, SPI/Funai, etc.) que se pautou pela não inclusão das culturas diferenciadas, por força de conquistas legitimadas pelas lutas dos movimentos sociais e pelo que está consagrado na legislação, hoje se propõe a valorizar as diversas culturas, dando-lhes legitimidade e visibilidade.

As escolas que atendem às Aldeias indígenas, localizadas na Flona do Tapajós, já são consideradas como indígenas tanto pela Secretaria Estadual de Educação do Pará quanto pela Secretaria Municipal de Educação de Belterra, e estão em processo de construção de seus projetos pedagógicos diferenciados. Em Marituba trabalham seis professores, dos quais apenas um é indígena, e existem 52 alunos matriculados em turmas do ensino fundamental regular, multisseriadas e EJA.

A Prefeitura Municipal criou a Coordenação Indígena, alocada na Secretaria de Planejamento e Gestão, para tratar exclusivamente dos interesses dos indígenas do município. Há também uma coordenação de ensino indígena, já atuando há dois anos, cuja tarefa central tem sido a assessoria na organização documental das escolas para fins de reconhecimento. No caso da Escola Indígena Munduruku da localidade de Bragança, constatamos que, embora ainda não contemple todos os requisitos legais, reveste-se de grande importância para a comunidade.

Considerando que a pesquisa também objetivava retratar a realidade da educação escolar indígena na localidade de Marituba com a utilização da fotografia, a seguir são apresentadas imagens que dão ao leitor a possibilidade de visualizar as condições concretas dos espaços destinados às aulas, bem como outras atividades do cotidiano da Aldeia. Todas as fotografias apresentadas a seguir pertencem ao arquivo pessoal dos autores deste artigo.

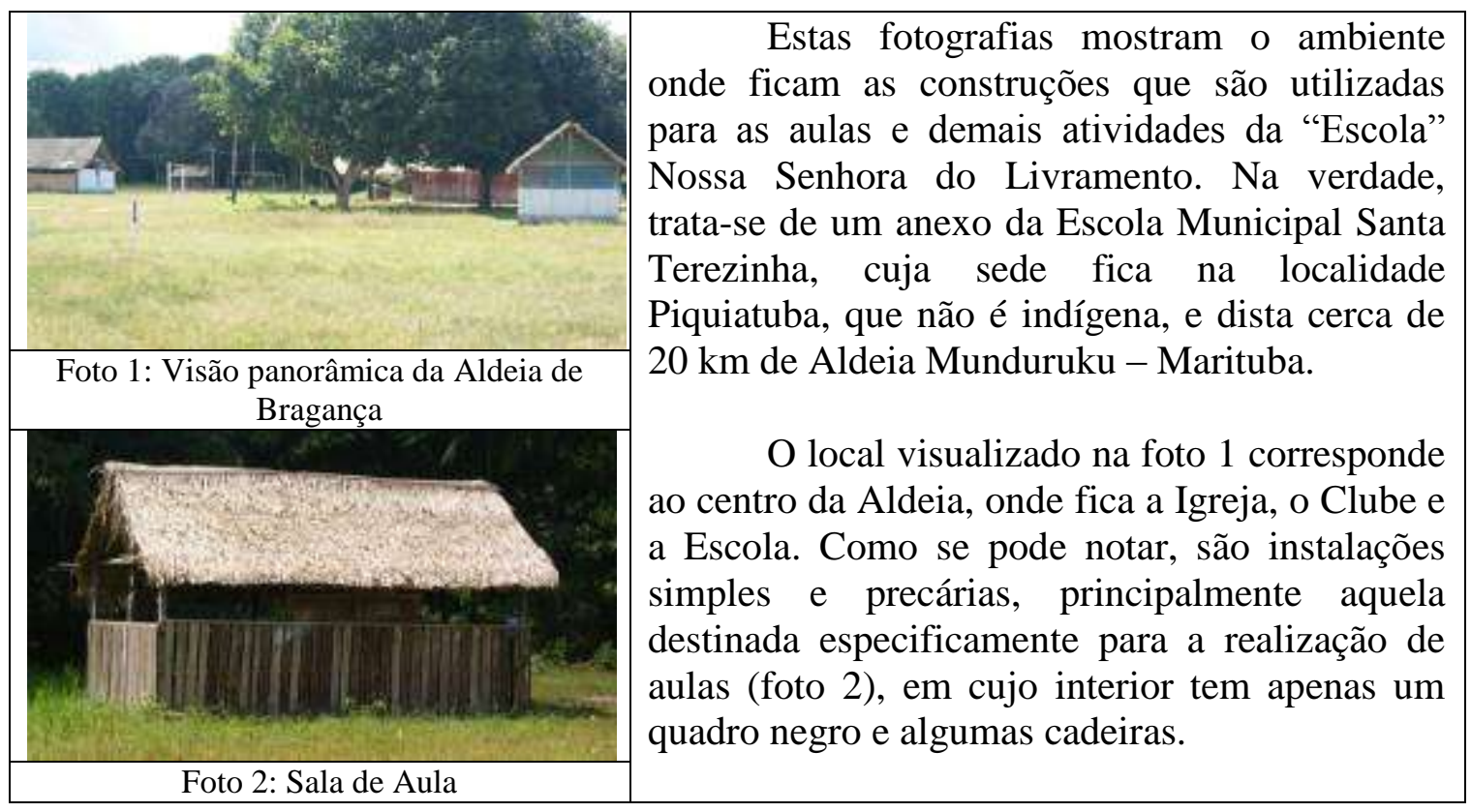




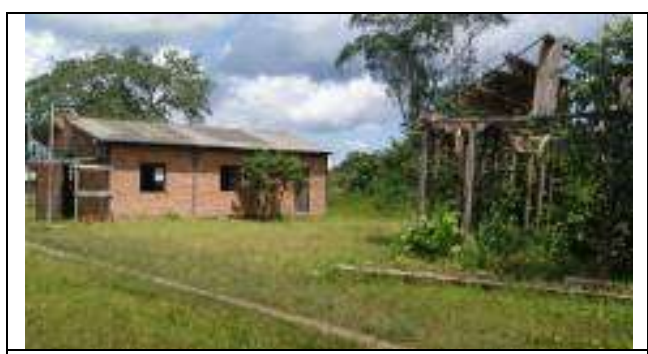

Foto 3: Igreja (atual, e as ruínas da anterior)

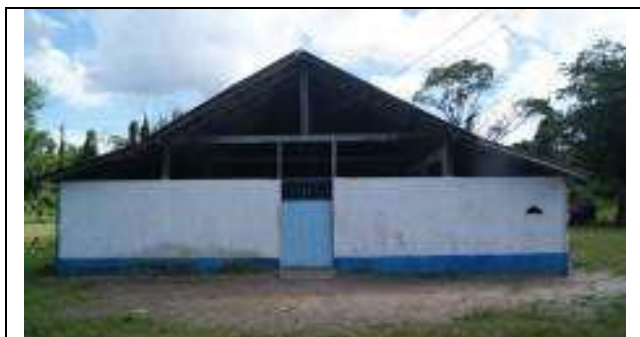

Foto 4: Clube (festas, ... e aulas)

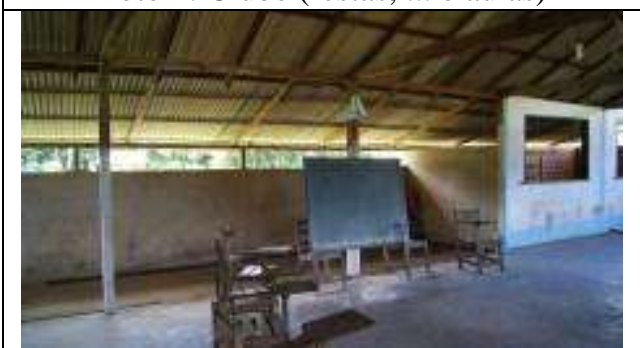

Foto 5: Interior do Barracao Comunitário

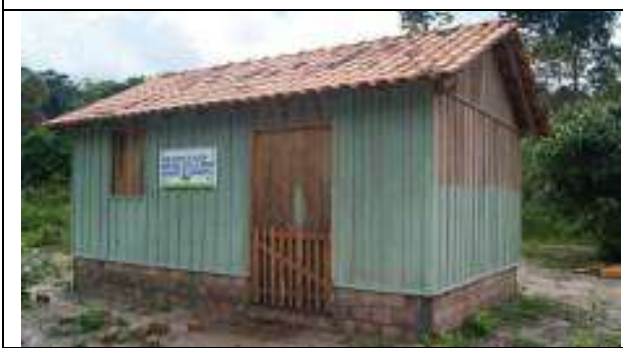

Foto 6: Biblioteca

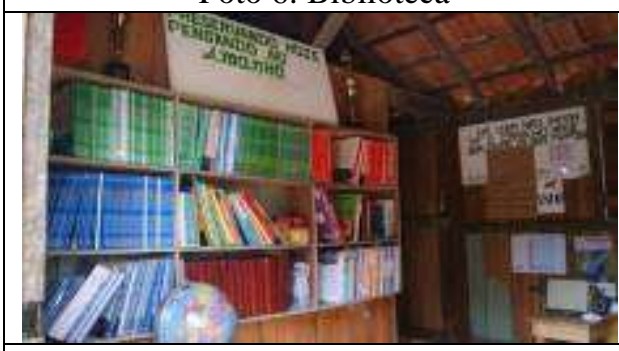

Foto 7: Interior da Biblioteca
$\mathrm{Na}$ Igreja (foto 3), dedicada a Nossa Senhora do Livramento, funciona a turma de EJA no período noturno, com o apoio de um sistema gerador de eletricidade a diesel que encontra-se bastante depreciado, exigindo manutenção com frequência. Geralmente opera das $18 \mathrm{~h} 30$, quando escurece, até por volta das $22 \mathrm{~h} 00$ (exceto em ocasiões festivas).

O barracão comunitário (foto 4), é onde ocorrem as festas, reuniões e eventos em geral. Trata-se de um tipo de construção que existe em praticamente todas as comunidades rurais da Amazônia. Quase sempre o prédio é de propriedade coletiva e tem a sua história associada à política e ao futebol. No interior do barracão há somente um quadro improvisado e algumas cadeiras que atendem aos alunos e aos professores (foto 5).

Das construções que compõem a Escola, a biblioteca (foto 6), é a que apresenta uma melhor condição estrutural. Mas é bastante limitada em termos de espaço, medindo 3 × 2 mts, não oferecendo condições para a realização de leituras e pesquisas em seu interior. Funciona mais como local para a guarda dos materiais de uso didático.

O acervo é constituído basicamente de livros didáticos enviados pelas Secretarias (do Estado ou do Município) e outros parcos recursos tais como o globo terrestre. Observa-se também um mimeógrafo a álcool, cartazes e troféus conquistados pela equipe de futebol nas competições que comumente ocorrem entre as comunidades (foto 7).

Durante o período das visitas in loco a Aldeia, percebemos que não há uma frequência regular de alunos ou de professores nas dependências da biblioteca.

As imagens são elucidativas da situação precária das instalações físicas da escola, e ao mesmo tempo indicam que, mesmo com toda a luta empreendida pela comunidade, ainda não mereceu por parte do poder público, um mínimo da devida atenção que a escola merece. 


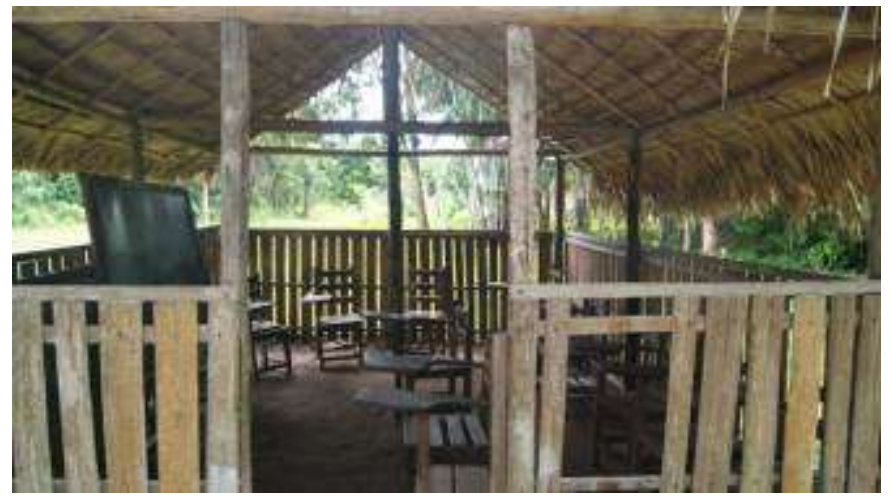

Foto 8: Interior da sala de aula

Aqui temos uma pequena amostra dos "retratos" da educação escolar (não apenas em Marituba, mas em outras localidades rurais): a precariedade das instalações e a ausência de equipamentos e de recursos didáticos, ao mesmo tempo em que se verifica o desperdício ou inadequação no uso dos recursos públicos, e o famoso "jeitinho" para que as atividades possam acontecer, apesar de todas as limitações e carências.

Esta constatação ganha maior relevância se considerarmos que existe um prédio inacabado, cuja construção está paralisada e em processo de deterioração, como se pode notar na sequência de imagens dispostas a seguir.

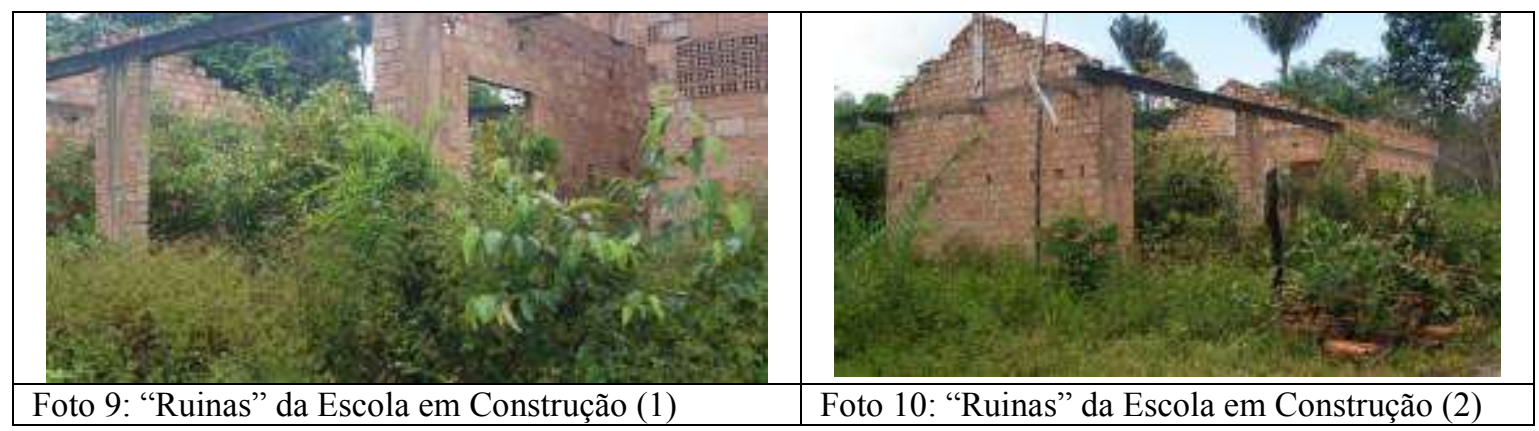

A sala de aula (foto 8 ) coberta de palha e em chão batido, contrasta com o prédio em alvenaria (foto 9) que está sendo destruído, antes mesmo de sua conclusão. A aula embaixo da árvore (uma frondosa mangueira) não é simplesmente para que seja integrada ao ambiente (foto 11), mas pelo fato de que apresenta melhores condições do que a escola. Aliás, é importante observar que a temperatura neste local, durante o dia, fica na faixa de 38 a $42^{\circ} \mathrm{C}$. Mesmo assim, ainda é mais "confortável" do que estar confinado na "sala de aula".

São estas as condições concretas nas quais se realiza a educação escolar indígena na Aldeia de Marituba, em Belterra. Mas, apesar das limitações, a escola é vista com respeito e esperança por parte de alunos, professores, e demais membros da comunidade indígena. Todos anseiam por uma educação que propicie condições de terem uma vida melhor, sem abrir mão de suas tradições culturais. 


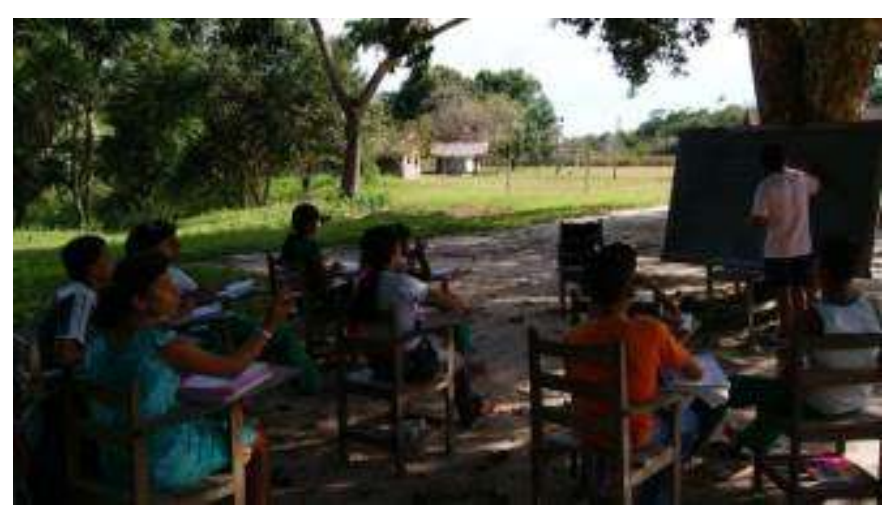

Foto 11: Aula embaixo da árvore

A escola também foi retratada em textos produzidos por 11 (onze) estudantes, das diferentes turmas, que aceitaram compor uma redação com duas partes. Na primeira, deveriam descrever a escola real, e na segunda escrever sobre a escola de seus sonhos. Além da estrutura física, muitos destacaram também as aulas e os professores, os quais receberam elogios pelo trabalho que desenvolvem. Não havia a necessidade de identificação. Vejamos inicialmente como a escola que vimos nas imagens é retratada por quem a frequenta na condição de estudante, em trechos selecionados e transcritos da forma que foram redigidos.

1) A minha escola ela é muito simplis, está faltando cadeira melho e quadro $[\ldots]$

2) [...] é feita de pau coberta por palhas, não é muito bom a condição da escola mas dar para estudar e também dar para aprender bastante. [...].

3) [...] as aulas que acontecem dentro desta pequena escola são as aulas de ciências, português, história, geografia, matemática, religião, estudos amazônicos, arte, educação física e a língua materna. As aulas são boas e tenho orgulho de aprender ainda mais com os meus professores.

4) [...] minha escola é cuberta de palha piso de barro sercado de ripa feita pelos indígenas e estudo de baicho de uma arvore as aulas acontece normal com disciplina e além disso temos a língua materna os professores são indígenas e não indígenas mesmo assim eles trabalham de acordo com o conteúdo e a realidade da aldeia.

5) A minha escola é bom por que é perto de casa; com relação a estrutura não é boa como diz o artigo constitucional brasileiro da educação, mas temos o contato natural, as aulas estão acontecendo e temos felicidade de estar estudando, mesmo sem prédio escolar adequado, os professores são bons por que são da aldeia e conhece a região, e acompanham a vida da comunidade [...]

6) A minha escola é um barracão e tem sala que é de madeira coberta de palha e cercado de ripa quando é quente não estudamos no barracão por causa do brasilite, as aulas são boas pois as disciplinas inclui a linga materna do povo muduruku [...].

7) [...] os professores trabalham como podem, o único material que eles utilizam são da natureza das nossas matas, e eles trabalham de acordo com o nosso povo. As aulas as vezes é bom, é as vezes é 
enjuada agente que não gosta de ficar até o fim nós quer pescar, caçar, jogar bola. [...]

8) A minha escola ela é muito bonita porque é muito ventilada e é uma escola a onde são poucos alunos que estuda e nós somos colegas e eu gosto muito dela. Gosto muito dos meus professores. [...]

9) [...] minha escola é feita de palha, ripa de pau-darco, piso de barro e os insetos invadem principalmente as formigas, minhocas, cupins e outros. As aulas são muito legais. Os professores são muito criativo, interessados e que tem orgulho de ser professor e eu também tenho orgulho deles por que eu estou aprendendo muito com eles e espero que eles continuem assim [...]

10) Na minha aldeia não tenho prédio escolar. A escola é feita de paú é cuberta de palha sercado de ripa, o piso de barro. [...]

11) [...] A minha escola é de palha e de ripa não tem banheiro mais eu tenho fé em Deus que eu vou estudar num colejo bem bonito. E o meus professores são bacana mais tem hora que eles tão bravo por que nós também preucuram, se nós ficasse calado nós não pegaria ralho.

Considerando que o grupo teve sua identidade reelaborada a partir das lutas que desenvolveu em defesa de sua permanência nas terras que habitavam quando do processo de criação da reserva ambiental Flona do Tapajós, ainda está muito presente a imagem idealizada de uma escola não indígena. Isto se revela também na descrição da escola dos sonhos, como se pode notar a seguir.

1) Eu queria que a minha escola fosse de alvenaria para que todos pudessem estudar com tranquilidade [...]

2) [...] eu gostaria de ter uma escola com 6 salas ventilado por dentro uma sala com computador no lado dela uma quadra de jogar futebol outro de vôleibol e uma quadra de capoeira.

3) $[. .$.$] eu queria ter uma escola que tenha arcodicionado ventilador sala$ com internete também com parque para eu brincar, e banheiro dentro, quadra de futebol aula de capoeira para incinar fazer artesanato aprender tocar, violão, bateria, e mais etc.

4) [...] eu gostaria de ter, uma escola de arvenaria com banheiro dentro, e três sala e uma secretaria e coberta de telhado e pisso de cimento. $\mathrm{E}$ ter uns quadros melhor e cadeiras melhoris.

5) [...] eu queria que foce como as de cidades grandes, louza de qualidade, cozinha equipada, livraria na escola, área de lazer, internete, comunicação com outros países; sei que tenho cultura natural, mas não vou perde-la por que é raiz; e hoje o mundo e desenvolvido que pressisa de estudo, meus pais não tiveram essa oportunidade, mesmo com minha idade hoje avançada quero continuar estudando na minha própria aldeia.

6) Eu gostaria ter uma escola grande com 8 salas de aula. Com salas de informática que tenha o ensino médio. [...] 
7) Eu queria que foce uma escola de qualidade como tem nas cidades, com o computador, livraria, cozinha boa, merenda sem atrazo, lousa de qualidade e comunicação.

8) [...] nós quer uma escola digna de nós índio aqui tem que ser de nosso jeito. É dificio falar em escola dos meus sonhos para mim só falta um prédio, mas viver na aldeia é muito bom aqui nós brinca e na escola também tem hora de brincar precisamos lutar para continuar formar nossas crianças dentro da nossa cultura para que ela não se perca de suas raízes. Meu avô diz que se os filhos saírem da nossa aldeia eles vam se perder no mundo dos brancos.

9) Eu quero uma escola linda, bonita que tenha banheiro, tenha computadores, 4 salas, creches, e também quadra de futebol, e também duas quadras de voleibol, esse que é o meu sonho eu quero que ela seja linda, telha, tijolo, lajotada. E também uma secretaria.

10) [...] uma escola diferenciada que tenha bastantes salas, secretaria, quadra de futebol, cozinha, banheiro. E quero professores que tenha bastante conhecimento como minha cultura e com meu povo. Só assim meu sonho será realizado.

11) Eu gostaria de estudar numa escola que me faz feliz. Mais eu tenho certeza que um dia eu vou ter uma escola bem bonita daquela escola que todas as pessoas que passar na frente dela vam ficar com inveja e que essa escola me faz feliz é eu vou estudar nela e aprender bastante eu e meus colegas. Uma escola que tivesse umas quatro sala e também banheiro e uma secretaria com todos os livros e dicionários e os lápis de cor. E com quadra de futebol esse e o meu sonho muito grande que eu tenho.

Nos trechos transcritos a partir das redações dos estudantes da escola indígena de Marituba, podemos constatar que são muitas as expectativas com relação a escola, mas ainda não existe clareza quanto a uma educação efetivamente intercultural específica e diferenciada. Depois de um longo período em que predominou a perspectiva igualitarista e universalista de educação, faz-se necessário, como aponta Rosilene Tuxá: "através de um modelo específico de educação, a reafirmação das identidades étnico-culturais indígenas, mostrando que são possíveis outros modos de entendimento e valorização da existência humana" (TUXÁ, 2010, p. 17). Assim como tem sido importante a reelaboração das identidades indígenas, da mesma forma se faz necessário a reelaboração dos processos educativos que estão presentes no cotidiano.

Com relação à pedagogia, entretanto, não consideramos que cada povo e cada escola tenha uma pedagogia própria. Entendendo a pedagogia como teoria que se reporta a uma prática educativa, pode-se afirmar que toda teoria pedagógica está articulada a uma prática, mas nem toda a prática educacional necessariamente constitui-se numa pedagogia. Uma pedagogia, como teoria e prática educacional, busca equacionar o problema da relação educador-educando, pressupondo que esta relação é o cerne da problemática do ensino e aprendizagem. Com base nisso, consideramos que a pedagogia histórico-crítica (PHC) oferece uma contribuição importante ao propor um método pedagógico no qual a prática social seja ponto de partida e ponto de chegada da ação educativa, de forma que professores e alunos travem uma relação fecunda na compreensão e encaminhamento da solução dos problemas concretos, 
[...] cabendo aos momentos intermediários do método identificar as questões suscitadas pela prática social (problematização), dispor os instrumentos teóricos e práticos para a sua compreensão e solução (instrumentação) e viabilizar sua incorporação como elementos integrantes da própria vida dos alunos (catarse). (Saviani, 2006 [s.p.]).

Trata-se, portanto, de uma educação que leve ao enfrentamento das formas opressoras presentes no modo capitalista de produção. Não há ingenuidade no que estamos afirmando, muito menos se acredita que a escola - em si e por si mesma - possa fazer a revolução, mas também não se despreza o potencial da escola em promover aprendizagens que estimulem formas organizacionais colaborativas e solidárias. Consideramos que, nessa direção, as comunidades indígenas que resistiram a mais de quinhentos anos de julgo, estão construindo formas alternativas de vida que, embora ainda muito dependentes dos recursos públicos e de organizações não governamentais, sinalizam para um ponto de chegada que se aproxima dos ideais preconizados pelos que sonham com a superação do modo de produzir a vida implantado com o advento da burguesia.

As pedagogias mais vinculadas aos interesses do capital enfatizam o "aprender a aprender", mas negam ou secundarizam as relações presentes neste processo. Estas pedagogias hegemônicas são formuladas, divulgadas e defendidas com a finalidade de formar o trabalhador necessário à manutenção de seu sistema. Uma pedagogia revolucionária se volta para o enfrentamento desta problemática, a partir de alguns pressupostos essenciais, partindo da compreensão de que é fundamental a relação educação e trabalho. Pelo trabalho, o homem vai respondendo aos desafios e necessidades, construindo novas necessidades e impulsionando o desenvolvimento de novas habilidades e conhecimentos, num processo incessante no qual se desenvolvem a técnica, a ciência e a tecnologia, permitindo aumentar a produtividade do trabalho e liberar progressivamente o homem do tempo despendido no reino da necessidade para o reino da liberdade.

Partimos do que afirma Marx nos "Manuscritos Econômicos e Filosóficos" (2004), obra em que o autor delineou pela primeira vez de forma sistemática a compreensão do homem enquanto ser da natureza que cria e recria pela sua atividade vital - o trabalho - a sua própria existência, diferenciando-se dos demais animais, que para garantir sua vida adaptam-se a natureza, pois já nascem regulados (geneticamente) para dar um mesmo padrão de respostas aos diferentes estímulos e necessidades que se apresentam ao longo da vida. Diferentemente dos animais, o homem, ao transformar a natureza também se modifica, ou seja, ele próprio, por sua práxis, se constrói como homem. Com esta compreensão, fica claro que necessita de um longo processo de apropriação dos elementos culturais que foi construindo ao longo da história para garantir sua vida, ou dito de outra forma, necessita ser educado para desenvolver-se como ser humano. Na escola, instituição na qual a educação se realiza de forma sistemática, o professor pode assumir basicamente três posturas distintas:

1) atuar como um transmissor de conhecimento. Neste caso, a ênfase recai totalmente sobre a figura do professor. Sua cultura, identificando-se com o padrão dominante da sociedade em que vive, é imposta a todos os alunos, desconsiderando por completo as particularidades culturais. Um professor assim concebido pode trabalhar eficientemente diversos conteúdos. Porém, joga na lata do lixo toda a riqueza representada pela pluralidade de saberes que os seus alunos carregam. Este, em linhas gerais, é o modelo pedagógico da Escola Tradicional.

2) O professor pode ainda atuar como facilitador do processo de ensinoaprendizagem. Um professor-facilitador estaria atento às particularidades de cada aluno, estimulando-o a desenvolver sua capacidade de argumentação sem, contudo, interferir em 
suas opiniões pessoais. O aluno é visto como agente no processo de construção de seu próprio conhecimento. Tal é, em síntese, o modelo pedagógico da Escola Nova. Essa concepção possui, porém, duas grandes falhas. Em primeiro lugar o educador não pode simplesmente estimular quaisquer opiniões pessoais dos educandos. Se um de meus alunos defende abertamente a homofobia, por exemplo, é inadmissível que eu como educador não me posicione, me mantenha "neutro" frente a esta questão ou outras que clamem por um debate aberto em sala de aula. Um professor que acredite agir com neutralidade ilude a si mesmo, pois sempre demonstra seu ponto de vista, ainda que inconscientemente.

3) Finalmente, o professor pode atuar como mediador. A ênfase, neste caso, não recai nem sobre o professor nem sobre o aluno, mas sobre a relação que se estabelece entre ambos. O educador, nesta ótica, seria aquele que estabelece uma ponte entre a cultura particular do aluno e os valores culturais da sociedade, em sentido mais amplo. Mediação entre o local e o nacional, entre o particular e o universal, considerando os conhecimentos historicamente produzidos pela humanidade. Aqui temos, em linhas gerais, a educação numa perspectiva histórico-crítica.

A partir das questões apontadas, considera-se que, no âmbito da PHC as escolas indígenas possuem uma certa vantagem sobre as escolas que em geral são frequentadas pela classe trabalhadora não indígena, uma vez que, passadas aquelas fases de imposição de um modelo estabelecido pelo colonizador externo e pelos colonizadores nacionais, vem se construindo em outros moldes, mesmo que ainda de forma lenta e com grandes carências, como se constatou com relação a escola indígena da aldeia Munduruku de Bragança. Mesmo assim, verifica-se que está em curso um processo de aperfeiçoamento de suas práticas com a incorporação das contribuições oriundas das reflexões críticas do campo pedagógico. Deste movimento acredita-se que surja uma escola onde os conteúdos escolares universais e locais sejam permanentemente reavaliados face às necessidades do próprio coletivo ao qual se destina, e onde os métodos de ensino estimulem a criatividade de alunos e professores, favorecendo o diálogo interrelacional com os conhecimentos historicamente produzidos. Assim, aumentam as chances para que a escola possa garantir a apropriação de conteúdos significativos para a comunidade na qual se situa, sem que isto represente isolamento, fragmentação ou fortalecimento de guetos que, por vezes, se apresentam como sinônimos de educação diferenciada.

\section{Conclusão}

Vimos ao longo deste artigo que o principal fato que impulsionou a organização das populações do baixo rio Tapajós foi a questão territorial, uma vez que ao ser criada a reserva extrativista da Floresta Nacional do Tapajós não foi assegurada a posse permanente da terra. A luta pela permanência na terra evoluiu para o movimento mais amplo que desembocou no reconhecimento dessas populações como indígenas. E nesse contexto, ganhou lugar também a reivindicação para que seja implantada a educação escolar indígena nas Aldeias, com o ensino da língua de seus antepassados Mundurukus, bem como o revigoramento de manifestações culturais e práticas já esquecidas pelos atuais moradores que tomaram a decisão de recriar suas identidades, mesmo enfrentando diversos obstáculos.

Em termos de Brasil, desde a colonização o processo educativo figura como elemento relevante nas formas de contato dos brancos em relação aos índios. Da catequização inicial até as políticas de integração em décadas mais recentes, a educação foi sempre usada com o objetivo de impor o modo de vida economicamente dominante. Mas a perspectiva intercultural vem reconfigurando epistemológica e pedagogicamente a instituição escola, inclusive não indígena, a qual funciona tradicionalmente tendo por base 
um currículo monocultural que homogeneíza as diferenças e acentua as desigualdades sociais. Nascida para ocultar e silenciar uma cultura dita primitiva e inferior, a escola agora se propõe a respeitar, valorizar, dar legitimidade e visibilidade as diversas culturas. E isto só será possível se houver o diálogo intercultural, as trocas de saberes e conhecimentos produzidos em escolas indígenas e escolas não indígenas. Estamos diante de um grande desafio, o de garantir um ensino de qualidade para todos e, ao mesmo tempo, respeitar a diversidade. Trata-se de construir uma nova escola pública com a participação de seus beneficiários.

Embora esteja em curso uma série de ações com vistas a efetiva implantação da educação escolar indígenas na área da Flona do Tapajós, ainda persistem problemas da fase anterior em que eram tratados apenas como caboclos, ribeirinhos ou populações tradicionais. A escola da Aldeia de Marituba, ainda não pode ser plenamente caracterizada como indígena. Para que alcance esta condição, é necessário que seja estruturada e organizada em sintonia com as conquistas e os avanços teóricos e práticos que foram alcançados em sintonia com os anseios e as expectativas dos próprios indígenas, considerando suas tradições, modos de vida, o passado e o futuro. A oferta da educação escolar, em todos os níveis, em diversas localidades indígenas, já se constitui uma realidade, mas ainda bastante restrita. Mesmo assim, representa uma ressignificação da própria escola.

\section{Referências}

BANIWA, Gersem. O Índio brasileiro: o que você precisa sobre os povos indígenas no Brasil. Coleção educação para todos. Brasília: MEC/Secad; LACED/Museu Nacional, 2006.

Educação escolar indígena: estado e movimentos sociais. In: Revista da FAEEBA Educação e Contemporaneidade. Salvador, v. 19, n 33, jan-jun 2010 [p. 35-49].

BARRETTO, Henyo T. Da Nação ao planeta através da natureza: uma abordagem antropológica das unidades de conservação de proteção integral na Amazônia brasileira. Tese (Doutorado em Antropologia). São Paulo: USP, 2001.

BARTOLOMÉ, Meliá A. As etnogêneses: velhos atores e novos papéis no cenário cultural e político. Mana: Estudos de Antropologia Social, Rio de Janeiro: Ed. UFRJ, v. 2, n. 1, p. 39-68, 2006.

BECKER, Bertha K. Repensando a questão ambiental no Brasil a partir da geopolítica. In: LEAL, M. C. (Ed.). Saúde, ambiente e desenvolvimento: uma análise interdisciplinar. São Paulo: Hucitec/Abrasco, 1992. v. 1. p. 127-152.

BRASIL. Constituição da República Federativa do Brasil. São Paulo: Saraiva, 2005.

Ministério da Educação. Secretaria de Educação Continuada, Alfabetização e Diversidade. As leis e a educação escolar indígena: programa Parâmetros em Ação de Educação Escolar Indígena. Brasília: MEC/SECAD, 2005.

Ministério da Educação. Secretaria de Educação Fundamental. Referencial curricular nacional para as escolas indígenas. Brasília: MEC/SEF, 1998.

Lei de Diretrizes e Bases da Educação Nacional. Brasília: MEC, 1996. 
BOURDIEU, Pierre et al. A miséria do mundo. 5. ed. Petrópolis: Vozes, 2003.

CIMI - Conselho Indigenista Missionário. Outros 500: Construindo uma nova história. São Paulo: Editora Salesiana, 2001

COHN, Clarice. Educação escolar indígena: para uma discussão de cultura, criança e cidadania ativa. In: Revista Perspectiva. Florianópolis v. 23, n 2, jul-dez 2005 [p. 485-515].

COUNDREAU, Henry. Viagem ao Tapajós. Belo Horizonte: Livraria Itatiaia/Ed. USP, 1977.

DI PAOLO, Pasquale. Cabanagem: a revolução popular na Amazônia. 3. ed. Belém: CEJUP, 1990.

DIAS, Aparecida; OLIVEIRA, Ilma. SOUSA, Kleber de. Formação continuada: relato de experiência dos professores indígenas Krikati. In: Anais do XXII EPENN. Manaus, 2011.

ESTERCI, Neide. Conflitos ambientais e processos classificatórios na Amazônia brasileira. In: ESTERCI, N.; LIMA, D.; LENA, P. (Eds.). Diversidade sociocultural e políticas ambientais. Boletim Rede Amazônica, Rio de Janeiro: IFCS, v. 1, n. 1, p. 51-62, 2002.

FREIRE, José Ribamar Freire. Trajetória de muitas perdas e poucos ganhos. In: Educação escolar indígena em Terra Brasílis. Tempo de novo descobrimento. Rio de Janeiro. IBASE: julho de 2004. [p. 11 a 31].

GRUPIONI, Maria Denise Fajardo. Do discurso e das ações: a educação intercultural como política pública. In: Cadernos de Educação Escolar Indígena. Barra do Bugres, v. 2, n 1, 2003. [p. 144$161]$.

HECK, Egon. LOEBENS, Francisco \& CARVALHO, Priscila. Amazônia indígena: conquistas e desafios. In: Estudos Avançados 19 (53), 2005. [p. 237-257].

IMAFLORA/MMA/IBAMA/Banco Mundial. Plano Diretor e mapeamento comunitário da margem direita do Tapajós. Programa Piloto para Proteção das Florestas Nacionais Tropicais do Brasil (PPG-7). Relatório final. Piracicaba, 1996.

IORIS, Edviges Marta. Identidades negadas, identidades construídas: processos identitários e conflitos territoriais na Amazônia. ILHA, volume 11 - número 2.

Na trilha do manejo científico da floresta tropical: indústria madeireira e florestas nacionais. Boletim do Museu Paraense Emílio Goeldi (Ciências Humanas), v. 3, n. 3, p. 289-309, 2008.

LINS E SILVA, Tatiana. 1980. Os curupiras foram embora: economia, política e ideologia em uma comunidade amazônica. Dissertação (Mestrado em Antropologia) - Universidade Federal do Rio de Janeiro, Rio de Janeiro, 1980.

MARX, K. Manuscritos económico-filosóficos. Prefacio: Jesús Ranieri. São Paulo: Boitempo Editorial, 2004.

MELIÁ, Bartolomeu. Educação Indígena e Alfabetização. São Paulo: Edições Loyola, 1978.

MINISTÉRIO DA EDUCAÇÃO. Brasília, 1999. O Governo Brasileiro e a Educação Escolar Indígena $<\mathrm{htt} / \mathrm{www} . \mathrm{mec}$.gov/sef/indígena/Ftp/>

MINISTÉRIO DA EDUCAÇÃO. Plano Nacional de Educação. Brasília, 1999 <http://www.mec.gov.br/sef/indigena/Ftp/PNE.doc> 
MINISTÉRIO DA EDUCAÇÃO. Referencial Curricular Nacional para as Escolas Indígenas. MEC/SEF: Brasília,1998.

MOREIRA NETO, Carlos Araujo. 1971. A política indigenista brasileira durante o século XIX. Tese (Doutorado em Antropologia) - Faculdade de Filosofia, Ciências e Letras, Rio Claro, 1971.

PACHECO, Lucilene dos Santos. Currículo intercultural, bilíngue e diferenciado: Trançados entre o RCNEI e educação escolar indígena. In: Anais Eletrônicos do IX Encontro Nacional dos Pesquisadores do Ensino de História 18, 19 e 20 de abril de 2011. Florianópolis/SC.

PNUD, UNESCO, UNICEF, BANCO MUNDIAL. Declaração Mundial sobre Educação para Todos e Plano para satisfazer as necessidades básicas de aprendizagem. Jomtien, Tailândia, 1990

PONCE, Aníbal. Educação e luta de classes. Ed. São Paulo, Cortez, 1991.

REIS, Arthur Cesar Ferreira. Santarém: seu desenvolvimento histórico. Rio de Janeiro: Civilização Brasileira, 1979.

Revista FAEEBA do Departamento de educação da Universidade do Estado do Bahia. Edição de número 33, jan/jun 2010.

SANTOS, Paulo R. Tapaiulândia. Santarém: ICBS/ACN Gráfica e Editora Tiagão, 1999.

SANTOS, Silvio Coelho dos. Educação e Sociedades Tribais. Porto Alegre: Movimento, 1975.

SAVIANI, Dermeval. História das idéias pedagógicas no Brasil. 2 Ed, Campinas, SP: Autores Associados, 2008.

SAVIANI, Dermeval. Verbete: Pedagogia Histórico-Crítica. IN: NAVEGANDO NA HISTÓRIA DA EDUCAÇÃO BRASILEIRA. Campinas : Graf. FE : HISTEDBR, 2006.

SILVA, Aracy Lopes da. \& FERREIRA, Mariana Kawall Leal (Org.). Antropologia, História e Educação: A questão indígena e a escola. São Paulo: Global, 2001.

SILVA, Aracy Lopes da. A educação indígena entre diálogos interculturais e multidisciplinares: introdução. In.: SILVA, Aracy Lopes da \& FERREIRA, Mariana Kawall (orgs). Antropologia, História e Educação. São Paulo, Editora Global: 2001. p. 09-25.

Mito, Razão, História e Sociedade: Inter-relações nos Universos Sócio-Culturais Indígenas. In. SILVA, Aracy Lopes da; GRUPIONE, Luís Donizete (Orgs). A Temática Indígena na Escola: novos subsídios para professores de $1^{o}$ e $2^{o}$ graus. Brasília: MEC/MARI/UNECO, 1995.

SILVA, Rosa Helena. BONIN, Iara. Pedagogia e escola indígena, escola e pedagogia indígena. Obtido em http://www.abmp.org.br/textos/61.htm

TASSINARI, Antonella Maria Imperatriz. Escola indígena: novos horizontes teóricos, novas fronteiras de educação. In.: SILVA, Aracy Lopes da \& FERREIRA, Mariana Kawall (orgs). Antropologia, História e Educação. São Paulo, Editora Global: 2001. p. 44- 70.

TUXÁ, Rosilene Cruz de Araújo. Gerenciamento da educação escolar indígena, poder público e a relação com o movimento indígena: experiência e reflexão. In: Revista da FAEEBA - Educação e Contemporaneidade. Salvador, v. 19, n 33, jan-jun 2010 [p. 51-60]. 
Notas

${ }^{1}$ Trata-se de um movimento de reafirmação étnica e cultural, de autorreconstrução de grupos culturalmente diferenciados, por meio de processos de etnogêneses (Sider, 1976; Hill, 1996; Bartolomé, 2006).

2 A emergência histórica do 'caboclo' como categoria social na Amazônia é tratada por Parker (1985) como resultado de "Ameríndios destituídos e privados culturalmente e descendentes mestiços engajados em inconstantes atividades de subsistência e coleta de produtos florestais (p. 35)".

${ }^{3}$ Vejamos as localidades e um breve apontamento histórico sobre elas: 1) em 1661, a Missão Tapajó, em frente à foz do Tapajós, onde hoje se encontra a cidade de Santarém; 2) em 1723, a Missão Tapajó foi transferida para a região do Rio Arapiuns, sob o nome de Missão de Nossa Senhora da Assunção dos Arapiuns, atual Vila Franca; 3) em 1722, a Missão de São José dos Maytapú, atual Pinhél, na margem esquerda do Tapajós, a $180 \mathrm{~km}$ ao sul de Santarém; 4) em 1723, a Missão de Iburari, ou Borary, atual Alter do Chão, na margem direita do Tapajós; e 5) em 1740, a Missão de Santo Inácio ou dos Tupinambaranas, atual Vila de Boim, na margem esquerda do Tapajós. Com exceção de Alter do Chão e Santarém, todos os demais locais se encontram no interior dos limites da Resex Tapajós-Arapiuns.

4 As populações nativas foram equivocamente denominados como "indígenas" pelos colonizadores portugueses que pensavam tratar-se de habitantes das Índias. Apesar disso, manteremos essa denominação pois é a usual entre os próprios nativos e, também, nas elaborações sobre o assunto, inclusive a legal.

${ }^{5}$ Não se está defendendo aqui uma perspectiva relativista de ciência e de conhecimento, mas a afirmação de que se tratam de povos diferenciados e que, igualmente, possuem diferentes concepções de mundo, de conhecimento, de ação no mundo e das relações entre homens, animais e as forças vitais ou espirituais que animam o mundo e a vida. Admitindo-se que se tratam de diferentes concepções e de que cada um dos povos indígenas possui formas próprias de representar o mundo e a vida, do ponto de vista educacional é fundamental que as diferentes concepções sejam focadas: uma como expressão da identidade tribal; outra como expressão dos conhecimentos historicamente produzidos pela humanidade. Não são conhecimentos que devam ser colocados em confronto, mas como expressões diferenciadas do mundo societário.
Recebido em junho-12
Aprovado em setembro-12 